\title{
Location as a Competitive Advantage for Entrepreneurship. An Empirical Application in the Region of Aragon (Spain).
}

\begin{abstract}
For entrepreneurs, decision making is present right from the start. The decision-making process in business has received extensive academic attention in recent decades. One of the first-order strategic decisions for an entrepreneur is where to locate the new business. The emergence of the multi-criteria decision analysis paradigm allowed several criteria to be considered when making a decision, which surpassed the previous single criterion decision paradigm. The Electre methodology pioneered this new paradigm and, among the evolutions of the Electre method, version IV is perhaps the least used. This paper aims to show a methodology to aid decision making for entrepreneurs, in particular the location decision. Thus, this study shows an example, an empirical application of Electre IV for locating a business, with the ultimate goal of providing companies with a ranking of alternatives to consider, such that it provides a competitive advantage if the choice agrees with the first positions of the final ranking.
\end{abstract}

Keywords: Location decision, entrepreneur, decision-making, Electre IV.

We gratefully acknowledge funding from MICINN-FEDER through research project ECO2012-36290C03-01and from through COMPETE research group.

\section{INTRODUCTION}

For entrepreneurs decision-making is present from the beginning of their activity. These early decisions will determine the ultimate success of new business (Ucbasaran et al., 2001).

The importance of entrepreneurship as an "economic engine” (Nissan et al., 2011), especially in small and medium size firms, reaffirms the need to apply methodologies that aid decision-making.

The creation of a new business requires making many decisions, some of which are crucial for the future. One of the first and most important decisions, is the choice of the location of the business (Baum and Haveman, 1997).

From the perspective of Business Economics and Entrepreneurship, one of the main objectives pursued by companies is competitiveness. Business decision-making at any level must ensure this is maintained, in those aspects related to business location as well. The use of methodologies to aid decision-making synthesises the evaluations of all alternative locations into a single indicator, according to the criteria used for analysing company competitiveness.

The location decision can be raised as a decision of whether to start the venture close to home or somewhere else. (Brush et al., 2008). When considering the options for locating a business the proximity to other companies with similar interests could be taken into consideration. The generation of synergies among firms (Miles et al., 2009) can lead companies, or their facilities, to be located, in groups, for example, industrial estates, industrial districts or technological parks, that can result in increased performance. For this reason, in the literature there are studies analyzing the competitive advantages obtained by locating in these clusters (Mas-Verdu et al., 2010).

The locations used in this paper are considered as alternatives for starting an entrepreneurial venture.

The alternatives for location used in this paper are special. Countries and towns are not considered as alternatives, nor are industrial parks. The alternatives used are clusters of villages and towns denominated counties. The differences observed among them allow this level of aggregation to be used.

The methodologies used to aid decision-making synthesises the evaluations of all alternative locations into a single indicator, according to the criteria used for analysing company competitiveness.

As part of the multi-criteria decision paradigm, this study specifically uses the Electre method, and within the family of these approaches, version IV. The reason for this is that it can be applied without the need to use weighting or the relative importance of the criteria underpinning the choice. Traditionally, the use of weighting in different methodologies has been criticised for its lack of objectivity. The Electre IV method does not require weighting, thereby avoiding this subjectivity issue in the study.

This study therefore analyses the problem of making specific business decisions regarding the location of a business. Studies such as Makino et al. (2004) and Lim et al. (2008), demonstrate the relationship between business performance and location. Another part of the literature has focused on the analysis of business or territory factors that generate competitive advantages (Zortea-Johnston et al., 2012). This 
paper analyses location from a different perspective.

The location factors that an entrepreneur can consider when choosing a location that provides competitive advantages may go beyond those representing the characteristics of the territory that could be chosen. Additional factors that determine the location of the company vary depending on the size of the business (Arauzo and Manjón, 2004). Large firms base their decisions on different criteria than small and medium-sized firms. For large firms, the decision-making process is built on objective arguments. For small and medium-sized firms, the arguments tend to be more subjective. In fact, they are usually linked to some personal aspect of the entrepreneur (geographical origin, previous experience in the sector or financial status, for example).

The approach of this study is normative, that is, it attempts to explain how decision-makers (entrepreneurs) should behave under certain conditions to obtain or maintain a competitive advantage. Therefore it does not follow the positive or descriptive approach (how companies make decisions) nor the prescriptive approach (presenting tools to help in making the decision). As Bell et al. (1988) pointed out, a descriptive analysis is interested in how and why individuals think and act; it is how they do something, while the positive or descriptive approach is what they do and the normative approach is what they should do.

This study is structured as follows: It begins with a summary of the theory of decision making, from the classic single criterion paradigm to the multi-criteria one. The next section is devoted to explaining the methodological foundations of the Electre methods and, more specifically, version IV of this family. Section 3 contains the sample used and results, and the study ends with the conclusions section.

\section{DECISION-MAKING: FROM THE SINGLE CRITERION PARADIGM TO THE MULTICRITERIA.}

The main objective of this work is to try to help the entrepreneur in the decision-making process, for which an application of the cited method is presented. We use the general characteristics of the territory as a reference for a generic company, although its subsequent implementation will require adaptation to the circumstances of each case.

The theory of decision making has been studied extensively in areas such as economics (Dimitras et al., 2001; Zopounidis and Hurson, 2001; Morais and Almeida, 2006) and engineering (Keeney and Raïfa, 1976; Roy and Hugonnard, 1982; Brans et al., 1986; Beccali et al., 2003).

The activities and tasks of organizations and companies involve management and, as an essential part of management, decision-making. If the decision is defined as a choice between two or more alternatives, this definition includes the two most important issues underpinning this study: firstly, the existence of several alternatives that can be chosen by the decision-maker, and secondly, the selection of one of these alternatives to be carried out. Also, Simon (1957) defines a decision as "the process by which many alternatives are reduced to the one finally chosen".

The decision-maker does an important part of the decision-making process internally. Simon (1960) classifies decisions into two groups: programmed (repetitive) decisions and non-programmed (new) ones, and these in turn determine the type of techniques used in decision-making. One of the sciences most widely used in decision-making is Operations Research. However, as with mathematical programming, its main drawback is the existence of a single objective to maximise or minimise. Mathematical programming is the set of mathematical techniques that deals with the general study of these optimisation problems in the single criterion decision framework.

This traditional approach to decision-making assumes that the decision-maker's preferences can be represented mathematically by a single function, the objective function, which can assign an order to the possible decisions. Each one is given a desirability index, by making certain assumptions on the rationality of the decision maker. The optimal solution to the decision problem is then found after using mathematical techniques.

Economic theory has relied on a simplified normative theory of decisions using a single criterion (e.g., profit) to properly define its preferences. Therefore, classical economics has identified profit as the ultimate objective, for both companies and employers, who seek to maximise profits. This is a simplistic view from the point of view of current Business Economics, which considers multiple objectives to be achieved by the company and each of these objectives can determine various courses of action. This is what Caballero and Romero (2006) called the Kuhnian crisis. The economic profit is a variable of reference and is used in most models, especially the neoclassical model, which is the dominant model in the study of firms. Lindenberg and Ross (1981) consider profit as the short term variable and use value 
for the long term, which is the present value of the profits

This viewpoint clashes with the empirical perception that decision-making agents do not optimise their decisions on a single objective, but rather are influenced by a range of often conflicting objectives.

They also pointed out two serious anomalies in the traditional or single criterion decision paradigm:

- In many real situations, decision-makers, whatever their characteristics, do not want to rank the possible solutions based on a single criterion, but rather using different criteria that reflect their individual preferences.

- Characterising the feasible set using constraints (algebraic equalities or inequalities) that can never be violated is not entirely realistic. Indeed, it is generally much more realistic to accept that a relaxation (violation) of the term of the right of some of the restrictions does not seriously affect the real context in which the decision problem is defined.

Considering a single criterion upon which to base a decision has the advantage of allowing a mathematically correct approach to the problem. However, representing the problem this way is not necessarily realistic primarily for two reasons (Maystre et al., 1994): when comparing several alternatives a single criterion is rarely used and preferences for a criterion are difficult to represent in a model in many cases. In multi-criteria decision-making, the results depend not only on how the problem is formulated, but also the procedure to define the applicable criteria.

Friedman (1990) argued that problems with multiple criteria are economic only, because if the decision is taken on the basis of a single criterion, the problem is established on the basis of a single criterion, the problem is technological. Zeleny (1982) emphasises the same idea, saying there is no decision-making unless there are at least two criteria. If there is only one criterion, a simple measurement and a search for a decision are sufficient.

The multi-criteria paradigm maintains that the decision agents seek to find a balance between the criteria, so that the preferred alternative meets the criteria considered to the maximum possible degree.

Rodriguez-Uria et al. (2004) state that flexibility and adaptability are important in multi-criteria decision methods, as any decision will be the result of a combination of conflicting objectives that a decision-maker has to face. Thus, a model explicitly showing the different criteria can be used as a tool for consensus building, which is one of the most interesting facets of multi-criteria analysis.

Multi-criteria decision-making is credited with many practical applications, especially in the areas of public and private investment, mainly because technicians not responsible for decision-making have developed the model, and because this methodology can incorporate various criteria that can satisfy all interested parties.

The Electre methodology used in this paper is a tool to aid decision-making in which a set of alternatives are evaluated according to criteria and then compared in pairs. The result is an array of alternatives from best to worst.

The reasons for using the Electre methodology, and which distinguishes it from other methodologies (Buchanan et al., 2007) are:

1. It eliminates the concept of a strong preference (alternative A is preferred to another, B, whenever A exceeds the valuation of B against a set criteria) and the concept of weak preference is introduced (doubt is introduced when valuations of A and B are similar). This is made possible by the use of pseudo-criteria, i.e. the scores achieved by each alternative for each criterion which can cause doubt in the decision maker such that the preference changes from strong to weak.

2. A very low score on a particular criterion is not compensated by a very high score on another criterion.

Figure 1 shows the steps.

\section{FIGURE 1}

A classification of these decision support techniques for can established according to the type of problems to be solved. They can be classified into two main groups based on modeling they perform for the overall preferences and aggregation they use to achieve the objectives. Thus, taking the classification made by Maystre et al. (1994) as a reference the following can be highlighted:

a) Complete Aggregation: Consists of aggregating the different points of view into a single function that is optimized. 
b) Partial Aggregation: Admits the incomparability between alternatives. These methods or techniques are instruments to obtain a shortlist from very broad groups of alternatives. An outranking relation constitutes a model of preference aggregation, and represents the particular case of two alternatives that are "incomparable". The Electre methodology is inside this group.

The choice of version IV was made on the basis that, besides being able to be used for problems of ranking, it does not require weights to be assigned to the criteria. Figure 2 summarizes this choice.

\section{FIGURE 2}

\section{ELECTRE IV METHODOLOGICAL FOUNDATIONS. RESULTS FROM EMPIRICAL APPLICATION}

The Electre methods (Elimination et Choix Traduisant la Realité) were created at the Lamsade centre (Laboratoire d'Analys et Modélisation des Systèmes pour l`Aide à la Decision) at the University of Paris IX (Dauphine) in 1968, when Bernard Roy and his collaborators developed the first Electre method. Since then, the Electre methods have been used widely across Europe, as evidenced by the abundant literature on these methods and their applications (Figueira et al., 2005).

The methods are based on defining the outranking relations ${ }^{1}$ between each pair of alternatives, stating that alternative $a_{i}$ outranks another $a_{k}$ if $a_{i}$ is "at least as good" as $a_{k}$ in "a majority" of the criteria, and when there is no criterion where it is "significantly lower".

To apply this methodology to help in deciding the location of an entrepreneurial venture all information necessary for its implementation and further development is obtained sequentially.

\subsection{Location alternatives}

For the empirical application, the Autonomous Community of Aragon in Spain was chosen as a possible location, which can be subdivided into 33 counties $^{2}$ as alternative locations for firms to move to. This new administrative division is a grouping of several municipalities into entities with their own responsibilities ${ }^{3}$.

The variables used in this paper are shown en Table 1 and are the result of previous research by the authors. A binomial logistic regression was performed in which the variables were: income level, population, demand sophistication level, number of unemployed workers, the distance to the capital of the province, the distance to a highway and the distance to a port. The dependent variable was a binary variable which captured the location and the explanatory variables income level and distance from the airport were found to be not significant.

\section{TABLE 1}

The following is the definition of the variables used in this study, which are also the variables found to be significant in the previous study:

a. Population: measures the population of the capital of the region. This variable has been used in the studies Deveraux et al. (2007) and Holl (2003).

b. Demand sophistication level: a summary variable that measures certain aspects of the population, such as the number of telephones, cars, banks and business activities.

c. Unemployment: measures the number of people in the region registered as unemployed in the INAEM offices. This has been used and an explanatory variable in the studies by Devereux et al., (2007) and Boudier and Bensebaa (2005).

d. Distance to a port: measures the distance from the capital of the region to the nearest port. Examples are found in the articles of Barrios et al., (2006) and Guimaraes et al. (2000).

\footnotetext{
1 “Surclassement” in French.

2 These regions are formed by several villages.

${ }^{3}$ See García and Muñoz, 1999
} 
e. Distance to motorway: measures the distance from the capital of the region to the nearest motorway. This variable is included in the articles by Manjón and Arauzo (2006) and Guimaraes et al. (2000).

There are previous studies using a similar number of criteria: Buchanan et al. (2007) used five decision criteria for locating a power plant and Teixeira (2005) used four criteria to select an industrial maintenance contract.

The sign favours the development of competitive advantages: regions with the largest populations, populations with the highest demand sophistication level, lowest unemployment, shortest distance to a port and shortest distance to the nearest motorway.

Evaluation of the alternatives according to the criteria considered is shown in Table 2. The data were obtained from the National Institute of Statistics (population), the Aragon Institute of Statistics (unemployment), the Caixa Yearbook (demand sophistication level of the population) and the Michelin Road Guide (distances to ports and motorways).

\section{TABLE 2}

The initial data need to be standardised for two reasons: firstly, because of differences in the measurement units (population and unemployment are expressed in number of people, the demand sophistication level is an index and the distances are measured in kilometres), and secondly because the multi-criteria method used may be biased towards solutions with higher achievable values.

There are several ways to normalise the values: the method chosen for this study was to divide the criterion value by the best value reached for that criterion. This may be a maximum or minimum, depending on the sense for which the criterion is considered. The resulting values are expressed as a percentage of the best value. If the criterion is to maximise, the expression is:

$$
\mathrm{V}_{\mathrm{i}}^{\mathrm{a}}=\frac{\mathrm{V}_{\mathrm{i}}}{\operatorname{MaxV}_{\mathrm{i}}}
$$

If the criterion is to minimise, the expression is:

$$
\mathrm{V}_{\mathrm{i}}^{\mathrm{a}}=\frac{\mathrm{V}_{\mathrm{i}}}{{\operatorname{Min} V_{\mathrm{i}}}}
$$

\subsection{Preference, Indifference and Veto thresholds}

Once the criteria are identified, the next step is to define the limits for preference $\left(\mathrm{p}_{\mathrm{i}}\right)$, indifference $\left(\mathrm{q}_{\mathrm{i}}\right)$ and veto $\left(\mathrm{v}_{\mathrm{i}}\right)$ for each.

Thresholds are used to take into account the imperfect nature of the evaluation of the actions. The introduction of thresholds leads to the use of pseudo-criteria and not real criteria.

There are several techniques to determine these values. Figueira et al. (2005) argues that there are no real values for these thresholds, but that the values chosen for them must be the most appropriate for expressing the imperfect nature of knowledge; in most companies these values are set directly by the decision-maker. Other authors (Rogers et al., 1999) carried out an alternative approach to set these values in a real way ${ }^{4}$. Also Dias and Mousseau (2006) proposed a method to infer the value for the veto threshold ${ }^{5}$. Finally, Roy himself says that there are cases when setting these thresholds is not relevant, and that real and not pseudo-criteria can be used.

Another approach to calculating the thresholds is that the thresholds can be set based on the standard deviation of the criteria value, in addition to not setting the veto threshold. Thus, the indifference threshold is set as the standard deviation and the preference threshold as twice the standard deviation as in Monterio-Gomes et al. (2009).

For this study the decision was made to set two different specifications depending on the threshold chosen. The first is the standard deviation proposal and the second, using real criteria, i.e. without setting thresholds. The reason for choosing these specifications was due to the lack of consultation with the decision-makers, i.e. the companies. The choice of Electre IV from the family of methods meant that subjective elements did not have to be included in setting criteria weighting. Following the same

\footnotetext{
${ }^{4}$ It is based on the psychology of human preference relations, and applies to non-compensatory models such as Electre.

${ }^{5}$ Using linear programming mathematical procedures.
} 
approach, setting threshold objectives is possible only by using some alternative approach to direct consultation with the employers for those values. From the alternatives for setting these thresholds described above, only the two chosen do not require these consultations to be performed. The aim of this study is to evaluate each location for providing competitive advantages, with no intention to influence the location decision.

Table 3 specifies the threshold values for the first specification, in addition to the objective pursued by each criterion.

\section{TABLE 3}

\section{Credibility matrix for the alternatives}

The credibility matrix for the alternatives is given by the degree of credibility ${ }^{6}$ providing the outranking relation. The construction of this matrix is based on the concepts of quasi-dominance, canonical dominance, pseudo-dominance and veto-dominance ${ }^{7}$.

The result is a table in which each pair of alternatives is assigned a value between 0 and 1 . The closer the value is to 1 , the greater the degree of credibility that is given to the outranking relation.

\subsection{Results and Ranking of Alternatives}

The next step in the Electre IV method is to arrange the alternatives based on the degree of credibility results, by carrying out an ascending and descending distillation process.

It also adds the average profitability of companies located in each region.

The results are shown in Tables 4 and 5.

\section{TABLE 4, TABLE 5}

If an entrepreneur decides to locate in the territory under study, (Autonomous Community of Aragon), the results obtained with the standard deviation threshold specification show that the two regions best placed for attracting investment are those of Zaragoza and Teruel, followed by Bajo Cinca and la Hoya de Huesca. At the other extreme, the worst placed are Sobrarbe, Campo de Belchite, Maestrazgo and Ribagorza. Thus, the more populated regions with the highest number of registered unemployed workers occupy the first positions of the ranking. By contrast, the lower positions are less populated locations with the lowest number of registered unemployed workers. However, sparsely populated regions such as Gúdar and Matarraña appear in intermediate positions, ahead of more populous regions, due to their evaluation regarding distance to the nearest port. The region of Calatayud is also noteworthy for being the fourth-highest region in population and unemployment, with negative demand sophistication level and distance to port values, which adversely affect its final position. Both tables show similar results, which makes the method robust.

It also shows that firms located in regions at the top are more profitable than those in the bottom of the ranking.

Another result shown in the table is with regard to the concept of incomparability shown by this family of models. The regions of Teruel and Zaragoza appear together at the top of the table, however it cannot be categorically stated which region is better. What can be affirmed is that these two regions, Teruel and Zaragoza, outrank all the others.

The results for the specification without thresholds, which considers real criteria, are very similar to the previous specification. In this case, la Hoya de Huesca joins Zaragoza and Teruel in the top position. This is logical, as they are the most populated regions and, in this specification with the thresholds removed, the concepts of indifference or weak preference have disappeared. Also, Bajo Aragon rises from the sixth to third position. Gúdar-Javalambre is noteworthy for being low in 3 criteria and high in the two relating to geographical location, given its proximity to Valencia, resulting in a decrease in the distances.

Another case that merits attention is Bajo Cinca, which is the ninth most populous region, however its location makes it particularly attractive for attracting investment: it is near a port and is also a major communications hub. Generally speaking, the more eastern regions are better positioned than the western ones, due to their proximity to the Mediterranean ports.

\footnotetext{
${ }^{6}$ This matrix gives values between 0 and 1 , such that the closer the value is to 1 , the greater the degree of credibility that is given to the outranking relation, while the closer it is to 0 , the lower the degree of credibility.

${ }^{7}$ For a full explanation of the methodology, see Maystre et al. (1994).
} 
Finally, Calatayud is worth noting, since it does not appear at the top of the ranking for the criteria considered, despite being the fourth most populated community. Being one of the regions farthest from a port means it appears in position 7 and 8 for the two model specifications. The same occurs with Valdejalón, which appears in an intermediate position (number 9 in both specifications), despite having an intermediate population and a good road infrastructure.

\section{CONCLUSIONS, LIMITATIONS AND FUTURE RESEARCH}

Decision making is present from the start for entrepreneurs. One of those initial decisions is where to locate the new business.

The specificities of the decisions of the initial location for an entrepreneur can be addressed by analysis through complex methodologies that help in the decision-making process. One of these methods is the Electre method which is based on a multi-criteria methodology.

This paper presents the location decision as one of the first decisions that the entrepreneur will have to make. To assist in making that decision a methodology to aid the decision making process is provided as well as an example of practical application. This example, although it has been applied to a specific alternative, can be used for any other alternatives. It aims to show the use and interpretation of this methodology for entrepreneurs.

Multi-criteria decision methodologies have been used many times and with varying results. From a review of the literature, it is clear that the single criterion paradigm has been superseded by the multicriteria, which is undoubtedly much more realistic.

Using a single indicator to summarise a set of criteria, with those evaluating various alternative locations, is aimed at providing evidence on the competitive advantages companies can gain if they are located in the regions appearing in the top ranking positions. If location as well as other sources provide a competitive advantage, companies located in these areas should achieve higher levels of performance.

The methodology (Electre IV) used overcomes the single criterion paradigm and has the following advantages: the objective treatment of information, compensation no alternative values for each attribute and the participation of all actors involved in the decision-making.

The version implemented in this study has no weighting or importance given to the decision criteria, and enables variables related to geographical location in the alternatives to play a decisive role.

The decision to choose a particular location, if it provides a competitive advantage for companies, must be based on a rigorous yet flexible process. A multitude of criteria must be established before making a decision in a rigorous manner, including the use of multi-criteria methodologies such as that used in this study.

The result of this study provides a ranking for location alternatives that verifies the existence of competitive advantages for entrepreneurs located there, derived from an application of version IV of the Electre method.

The districts that placed higher in the final rankings for the criteria used in this study are the most populous ones as well as the best located geographically. Companies wishing to gain a competitive advantage and locate in Aragon should be based in those regions. This does not exclude the rest of the counties; however, the probability of attracting investment to these areas is lower. These results are consistent with the criteria used.

All of the counties occupying the lower positions in the final rankings have three factors in common: small population, low unemployment and poor communications. The regions of Ribagorza, Campo de Belchite and Maestrazgo are the farthest from a motorway. This fact highlights the importance of public investment in infrastructure.

The Autonomous Community used as a basis for this study has great business potential, primarily due to its geographical location is completed with firms differentials results depending on their location. However, there are still counties where the presence of the business sector is low, which highlights the scarce advantage taken of the excellent geographical location.

Some of the limitations of this research, and the conclusions reached, give rise to a number of additional lines of research that could allow the results obtained in this study to be completed and eventually reaffirm the conclusions that have been drawn.

a. The use other versions of the Electre method. In these cases the use of primary data should 
considered to aid in determining the thresholds to be used, or even for setting the relative weight of the criteria being considered. The use of secondary data in this study provides objectivity but has the problem of assigning an equal weight to all decision criteria. Drawing on surveys in which decision makers assign importance to the decision criteria could complete the results obtained.

b. The inclusion of new variables in the criteria that are taken into consideration for generating the ranking. Adding new criteria, in addition to the five used, will provide a ranking of the rankings more closely related to the interests of the entrepreneurs. However this line of research would require the availability of additional data that is often difficult to obtain.

c. The same analysis could be performed by business sectors. Assuming that all entrepreneurs, regardless of the sector they pertain to, make decisions valuing the decision criteria equally is a hypothesis that can be very restrictive.

\section{REFERENCES}

ARAUZO, J.M.; CAROD, M.C. (2004): "Firm Size and Geographical Aggregation: An Empirical Appraisal in Industrial Location”. Small Business Economics, Vol. 22, Issue 3-4, pp. 299-312.

BARRIOS, S.; STROBL, E; GÖRG, H. (2006): "Multinational's location choice, agglomeration economies and public incentives”. International Regional Science Review, Vol. 29, Issue1, pp. 81-107.

BAUM, J.A., HAVEMAN, H.A. (1997): "Love the Neighbour? Differentation and Agglomeration in the Manhattan Hotel Industry, 1898-1990”. Administrative Science Quarterly, Vol. 42, pp. 304-338.

BECCALLI, M.; CELLURA, M.; MISTRETTA, M. (2003): "Decision-making in energy planning. Application of the Electre Method at regional level for the diffusion of renewable energy technology”. Renevable Energy, Vol 28, Issue 13, pp. 2063-2087.

BELL, D.E.; RAIFFA, H.; TVERSKY, A. (1988): “Descriptive, Normative and Prescriptive Interactions in Decision Making” in D. E. Bell, H. Raiffa and A. Tversky (eds.) Decision-Making: Descriptive, Normative and Prescriptive Interactions, pp. 9-30. Ed: Cambridge University Press

BOUDIER, F.; BENSABAA, F. (2005): “Agglomeration economies and location choice: "Foreign direct investment in Hungary". The Economics of Transition, Vol. 13, Issue 4, pp. 605-628.

BRANS, JP.; VINCKE, PH.; MARRSCHAL B. (1986): "How to select and how to rank projects: the PROMETHEE method”. European Journal of Operational Research, Vol. 24, pp. 228-238.

BRUSH, C.G., EDELMAN, L.F.; MANOLOVA, T.S. (2008): “Effects of Initial Location, Aspirations, and Resources on Likelihood of First Sale in Nascent Firms”. Journal of Small Business Management. Vo.l 46, Issue 2, pp. 159-182.

BUCHANAN, J.; VANDERPOOTEN, D. (2007): "Ranking projects for an electricity utility using ELECTRE III”. International Transactions in Operational Research, Vol. 14, pp .309-323.

CABALLERO, R.; ROMERO, C. (2006): “Teoría de la Decisión Multicriterio: un ejemplo de Revolución Científica Kuhniana”. Boletín de la Sociedad de Estadística e Investigación Operativa, Vol 22, pp. 9-16.

DEVEREUX, M.; GRIFFITH, R.; SIMPSON, H. (2007): “Firm Location Decisions, Regional Grants and Agglomeration Externalities”. Journal of Public Economics, Vol. 91, pp. 413-435.

DIAS, l.; MOUSSEAU, V. (2006): “Inferring Electre_s veto-related parameters from outranking examples”. European Journal of Operational Research, Vol. 170, pp 172-191.

DIMITRAS, A.I.; ZOPOUNIDIS, C.; HURSON, C. (2001): “Assessing financial risks using a multicriteria sorting procedure: The case of country risk assessment”. Foundations of Computing, and Decision Sciences, Vol. 29, pp. 97-109.

FIGUEIRA, J.; MOUSSEAU, V.; ROY, B. (2005): Electre Methods” in “Multiple Criteria Decision Analysis: State of the Art Surveys. Ed. Springer.

FRIEDMAN, M (1990): Teoría de Precios. Ed. Alianza. Madrid.

GARCÍA-CEBRIÁN, L.I.; MUÑOZ-PORCAR, A. (1999): "Multicriteria Analysis of the potential for industrial development within the counties of Aragón”. Foundations of Computing, and Decision Sciences, Vol. 34, pp. 87-104.

GUIMARAES, O.; FIGUEIREDO, O.; WOODWARD, D. (2000): “Agglomeration and the location of 
Foreing Direct Investment in Portugal”. Journal of Urban Economics, Vol. 47, pp. 115-135.

HOLL, A. (2004): "Manufacturing location and impacts of road transport infrastructure: Empirical Evidence from Spain”. Regional Science and Urban Economics, Vol. 34, pp. 341-363.

KEENEY R.L.; RAÏFA H. (1976): Decision with multiple objectives: Preferences and value tradeoffs. Wiley, New York

S.B. LIM; D. RIBEIRO; S.M. LEE (2008): "Factors affecting the performance of entrepreneurial service firms”. The Service Industries Journal, Vol. 28, Issue 7, pp 1003-1013.

LINDENBERG, E.B., ROSS, S.A. (1981): "Tobin's $q$ Ratio and Industrial Organization." Journal of Business, Vol. 54, pp. 1-32.

MANJÓN, M.C.; ARAUZO, J. M. (2006): “La Localización de nuevos establecimientos industriales: estudios previos y evidencia para los municipios catalanes”. Ekonomiaz, Vol. 62, Issue 2, pp. 40-69.

MAS-VERDU, F.; RIBEIRO-SORIANO, D.; ROIG-DOBON, S. (2010): "Regional development and innovation: the role of services”. The Service Industries Journal, Vol. 30, Issue 5, pp. 633-641.

MAKINO, S.; ISOBE, T.; CHAN, C. (2004): “Does country matter?” Strategic Management Journal, Vol. 25, pp.1027-1043.

MAYSTRE, L.Y.; PICTET, J.; SIMONS, J. (1994): Méthodes Multicritères Electre. Description, conseils pratiques et cas d'application à la gestion environnementale. Presses Polytechniques Universitaires Romandes.

MILES, M.; MUNILLA, L.; DARROCH, J. (2009): “Sustantinable corporate entrepreneurship”. International Entrepreneurship and Management Journa,. Vol. 5, pp. 65-76.

MONTEIRO-GOMES, LF.: DUNCAN-RANGEL, LA.; AMADEL-MOREIRA, R. (2009): "Using Electre IV in the promotion of social and economic development: a case study in Rio de Janeiro." Foundations of Computing an Decision Sciences, Vol. 34, Issue 3, pp. 155-172.

MORAIS, D.C; ALMEIDA, AT (2006): "Water supply system decision making using multicriteria analysis”. Water SA., Vol 32, pp. 229-235.

NISSAN, E.; GALINDO-MARTÍN, M.A.; MÉNDEZ-PICAZO, M.T. (2011): "Relationship between organizations, institutions and economic growth process". International Entrepreneurship and Management Journal, Vol. 7, Issue 3, pp. 311-324.

RODRÍGUEZ-URÍA, M. V.; BILBAO-TEROL, A.; ARENAS-PARRA, M.; PÉREZ-GLADISH, B. ANTOMIL-IBIAS J. (2004): Las matemáticas como soporte de las decisiones en economía y empresa. Rect@, Vol. 1.

ROGERS, M.; BRUEN, M.; MAYSTRE, L.Y. (1999): Electre and decision support. Methods and Aplications in Engineering and Infrastructure Investment. Kluver Academic Publishers, Boston.

ROY B. (1968): "Classement et choix en présence de points de vue multiples, la méthode ELECTRE” R.I.R.O., Vol 2.

ROY, B.; HUGONNARD, J. (1982) : “Réponse à Monsieur Gargaillo”. Les Cahiers Scientifiques de la Revue Transports, Vol 7, pp. 58-64.

SIMON, H. A. (1957): Administrative behavior (Vol. 4). New York, NY: Free Press.

SIMON, H. A. (1960): The new science of management decision. New York, Ed: Harper \& Row. NY.

TEIXEIRA, A. (2005): "Multicriteria Modelling of Repair Contract Based on Utility and ELECTRE I Method with Dependability and Service Quality Criteria”. Annals of Operation Research, Vol. 138, pp. 113-126.

UCBASARAN, D., WESTHEAD, P.; WRIGHT, M. (2001): "The Focues of Entrepreneurial Research: Contextual and Process Issues”. Entrepreneurship Theory and Practice, Vol. 25, Issue 4, pp. 57-80.

ZELENY, M. (1982): “Multiple Criteria Decision Making. McGraw Hill. New York.

ZOPOUNIDIS, C.; HURSON, C. (2001): “Portfolio selection and multicriteria analysis” In C. Floudas and P. Pardalos (eds.) Encyclopedia of Optimization, Vol. IV, pp. 310-322. Kluwer Academic Publishers, Dordrecht, 2001. 
ZORTEA-JOHNSTON, E.; DARROCH J.; MATEAR, S. (2012): “Business orientations and innovation in small and medium sized enterprises”. International Entrepreneurship and Management Journal, Vol. 8, pp. $145-164$.

Table 1. Variables used and statistical sources

\begin{tabular}{lccc}
\hline Variable & Sign & Statistical source & Objective \\
\hline Population & Positive & Nat. Inst. of Statistics & Maximise \\
Demand sophistication level & Positive & La Caixa Yearbook & Maximise \\
Unemployment & Positive & Arag. Inst. of Statistics & Maximise \\
Distance to a port & Negative & Michelin Guide & Minimise \\
Distance to a motorway & Negative & Michelin Guide & Minimise \\
\hline
\end{tabular}

Table 2. Value of the alternatives regarding the criteria used.

\begin{tabular}{lrrrrr}
\hline & Population & $\begin{array}{c}\text { Population } \\
\text { services } \\
\text { level }\end{array}$ & $\begin{array}{c}\text { Unemploymen } \\
\text { t }\end{array}$ & $\begin{array}{r}\text { Distance } \\
\text { to a port }\end{array}$ & $\begin{array}{r}\text { Distance to } \\
\text { a motorway }\end{array}$ \\
\hline Alto Gállego & 8,789 & 23 & 226 & 259 & 38 \\
\hline Andorra-Sierra de Arcos & 7,869 & 19 & 414 & 179 & 111 \\
\hline Aranda & 3,444 & 9 & 121 & 265 & 21 \\
\hline Bajo Aragón-Caspe & 7,587 & 21 & 440 & 139 & 21 \\
\hline Bajo Aragón & 14,383 & 37 & 655 & 141 & 58 \\
\hline Bajo Cinca & 12,868 & 35 & 362 & 118 & 1 \\
\hline Bajo Martín & 1,883 & 5 & 130 & 175 & 51 \\
\hline Campo de Belchite & 1,570 & 4 & 174 & 250 & 29 \\
\hline Campo de Borja & 4,313 & 11 & 310 & 290 & 14 \\
\hline Campo de Cariñena & 3,411 & 9 & 152 & 250 & 14 \\
\hline Campo de Daroca & 2,099 & 6 & 59 & 213 & 14 \\
\hline Cinca Medio & 15,395 & 38 & 516 & 143 & 51 \\
\hline Cinco Villas & 16,249 & 40 & 719 & 197 & 48 \\
\hline Comunidad de Calatayud & 19,279 & 45 & 806 & 280 & 1 \\
\hline Comunidad de Teruel & 32,304 & 82 & 1,189 & 125 & 1 \\
\hline Cuencas Mineras & 3,192 & 8 & 255 & 218 & 55 \\
\hline D.C. Zaragoza & 626,081 & 1,407 & 20,915 & 248 & 1 \\
\hline Gúdar-Javalambre & 1,391 & 4 & 168 & 116 & 22 \\
\hline Hoya de Huesca & 47,609 & 118 & 1,451 & 220 & 1 \\
\hline Jacetania & 12,063 & 34 & 316 & 220 & 1 \\
\hline Jiloca & 4,198 & 12 & 230 & 215 & 1 \\
\hline La Litera & 8,639 & 23 & 265 & 158 & 42 \\
\hline Maestrazgo & 722 & 8 & 44 & 191 & 110 \\
\hline Matarraña & 2,018 & 6 & 132 & 142 & 55 \\
\hline Monegros & 3,987 & 11 & 293 & 250 & 40 \\
\hline Ribagorza & 3,266 & 10 & 191 & 256 & 81 \\
\hline Ribera Alta del Ebro & 5,907 & 14 & 564 & 240 & 1 \\
\hline Ribera Baja del Ebro & 2,075 & 5 & 179 & 195 & 1 \\
\hline Sierra de Albarracín & 1,045 & 3 & 99 & 180 & 25 \\
\hline Sobrarbe & 838 & 7 & 185 & 285 & 80 \\
\hline Somontano de Barbastro & 15,490 & 40 & 590 & 167 & 50 \\
\hline Tarazona y el Moncayo & 10,671 & 25 & 610 & 184 & 19 \\
\hline Valdejalón & 6,353 & 16 & 521 & 310 & 1 \\
\hline & & & & & \\
\hline
\end{tabular}

Table 3. Preference, indifference and veto threshold values

\begin{tabular}{cccccc}
\hline Criterion & Population & $\begin{array}{c}\text { Demand } \\
\text { sophistication } \\
\text { level }\end{array}$ & Unemployment & $\begin{array}{c}\text { Distance to a } \\
\text { port }\end{array}$ & $\begin{array}{c}\text { Distance to a } \\
\text { motorway }\end{array}$ \\
\hline $\mathrm{q}_{\mathrm{i}}$ & 0.17 & 0.17 & 0.17 & 0.47 & 31.33 \\
$\mathrm{p}_{\mathrm{i}}$ & 0.34 & 0.34 & 0.34 & 0.93 & 62.67 \\
$\mathrm{v}_{\mathrm{i}}$ & 0 & 0 & 0 & 0 & 0 \\
\hline
\end{tabular}


Table 4. Final ranking of alternatives according to standard deviation specification for setting thresholds.

\begin{tabular}{ccc}
\hline Position & Alternative & Average profitability \\
\hline $\mathbf{1}$ & Comunidad de Teruel & $7.34 \%$ \\
& Delimitación Comarcal de Zaragoza & $8.05 \%$ \\
\hline $\mathbf{2}$ & Bajo Cinca & $7.73 \%$ \\
\hline $\mathbf{3}$ & Hoya de Huesca & $7.58 \%$ \\
\hline \multirow{2}{*}{ Bajo Aragón-Caspe } & $2.67 \%$ \\
& Cinco Villas & $7.24 \%$ \\
\multirow{2}{*}{$\mathbf{5}$} & Jacetania & $7.36 \%$ \\
& Somontano de Barbastro & $7.38 \%$ \\
\hline \multirow{2}{*}{$\mathbf{C}$} & Cinca Medio & $7.55 \%$ \\
& Tarazona y el Moncayo & $3.23 \%$ \\
\hline \multirow{2}{*}{$\mathbf{7}$} & Bajo Aragón & $7.44 \%$ \\
& La Litera & $7,15 \%$ \\
\hline \multirow{2}{*}{$\mathbf{8}$} & Comunidad de Calatayud & $7.14 \%$ \\
& Jiloca & $3.54 \%$ \\
\multirow{2}{*}{$\mathbf{9}$} & Ribera Alta del Ebro & $6,62 \%$ \\
\hline & Gúdar-Javalambre & $3,57 \%$ \\
& Ribera Baja del Ebro & $7,88 \%$ \\
\hline \multirow{2}{*}{$\mathbf{1 0}$} & Alto Gállego & $11.24 \%$ \\
& Matarraña & $7,22 \%$ \\
& Valdejalón & $5,46 \%$ \\
\hline \multirow{2}{*}{$\mathbf{1 1}$} & Andorra-Sierra de Arcos & $3.92 \%$ \\
& Campo de Borja & $6,98 \%$ \\
\hline $\mathbf{1 2}$ & Campo de Cariñena & $6,74 \%$ \\
\hline $\mathbf{1 3}$ & Monegros & $7,33 \%$ \\
\hline $\mathbf{1 4}$ & Campo de Daroca & $3,26 \%$ \\
\hline \multirow{2}{*}{$\mathbf{1 5}$} & Cuencas Mineras & $3.66 \%$ \\
\hline $\mathbf{1 6}$ & Bajo Martín & $2.15 \%$ \\
\hline & Sierra de Albarracín & $3,36 \%$ \\
\hline
\end{tabular}

Table 5. Fnal ranking of alternatives using the real criteria specification.

\begin{tabular}{|c|c|c|}
\hline Position & Alternative & Average profitability \\
\hline \multirow{3}{*}{1} & Comunidad de Teruel & $7,34 \%$ \\
\hline & Delimitación Comarcal de Zaragoza & $8,05 \%$ \\
\hline & Hoya de Huesca & $7.58 \%$ \\
\hline 2 & Bajo Cinca & $7,73 \%$ \\
\hline \multirow{5}{*}{3} & Bajo Aragón - Caspe & $2,67 \%$ \\
\hline & Bajo Aragón & $7,44 \%$ \\
\hline & Cinco Villas & $7,24 \%$ \\
\hline & Gúdar-Javalambre & $3,57 \%$ \\
\hline & Tarazona y el Moncayo & $3,23 \%$ \\
\hline \multirow{3}{*}{4} & Jacetania & $7,36 \%$ \\
\hline & Ribera Alta del Ebro & $6,62 \%$ \\
\hline & Somontano de Barbastro & $7,38 \%$ \\
\hline 5 & Cinca Medio & $7,55 \%$ \\
\hline 6 & La Litera & $7,15 \%$ \\
\hline 7 & Jiloca & $3,54 \%$ \\
\hline \multirow{2}{*}{8} & Comunidad de Calatayud & $7,14 \%$ \\
\hline & Ribera Baja del Ebro & $7,88 \%$ \\
\hline \multirow{5}{*}{9} & Alto Gállego & $11,24 \%$ \\
\hline & Matarraña & $7,22 \%$ \\
\hline & Campo de Daroca & $3,26 \%$ \\
\hline & Monegros & $7,33 \%$ \\
\hline & Valdejalón & $5,48 \%$ \\
\hline \multirow{2}{*}{10} & Andorra-Sierra de Arcos & $3,92 \%$ \\
\hline & Cuencas Mineras & $3,66 \%$ \\
\hline \multirow{3}{*}{11} & Bajo Martín & $2,15 \%$ \\
\hline & Campo de Borja & $6,98 \%$ \\
\hline & Sierra de Albarracín & $3,36 \%$ \\
\hline 12 & Campo de Cariñena & $6,74 \%$ \\
\hline \multirow{2}{*}{13} & Aranda & $1,80 \%$ \\
\hline & Maestrazgo & $0,79 \%$ \\
\hline \multirow{2}{*}{14} & Campo de Belchite & $3,90 \%$ \\
\hline & Ribagorza & $4,81 \%$ \\
\hline 15 & Sobrarbe & $3,87 \%$ \\
\hline
\end{tabular}


FIGURE 1

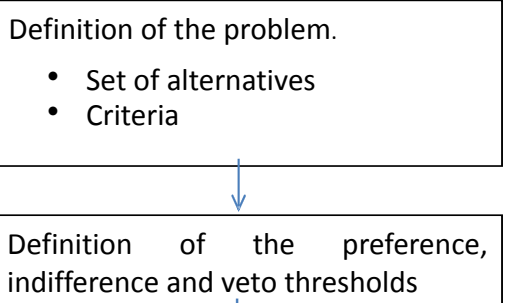

Alternative $a_{i}$ is superior to another, $a_{k}$, if $a_{i}$ "is at least as good as" $a_{k}$ for "the majority" of the criteria, and there are no criteria where it is "substantially inferior"

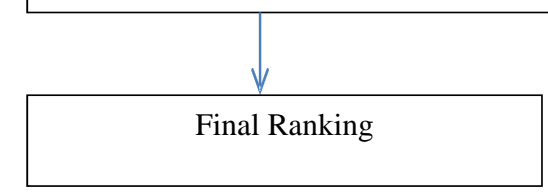




\section{FIGURE 2}

